\title{
Short communication \\ Chromatographic separation of amyloglucosidase from the mixtures of enzymes
}

\author{
Sebnem Harsa ${ }^{a, *}$, Shintaro Furusaki ${ }^{b, 1}$ \\ a Department of Food Engineering, Faculty of Engineering, Izmir Institute of Technology, Gaziosmanpasa Blv. No. 16, Cankaya, Izmir 35230, Turkey \\ ${ }^{\mathrm{b}}$ Department of Applied Life Science, Sojo University, 4-22-1 Ikeda, Kumamoto 860-0082, Japan
}

Received 9 November 2000; accepted 5 April 2001

\begin{abstract}
An affinity chromatographic separation of amyloglucosidase (AMG) enzyme using $\beta$-cyclodextrin-chitosan matrix was investigated in this study. The adsorbent selectively adsorbed AMG from the mixtures of enzymes (lactase and $\alpha$-amylase), and this selectively bound AMG was eluted from the column in two steps with a recovery yield of about $72 \%$. A small fraction of AMG and other contaminating proteins did not bind to the column specifically and were eluted easily. Purified AMG was visualised on the sodiumdodecyl sulphate-polyacrylamide gel electrophoresis (SDS-PAGE) experiments. (C) 2001 Elsevier Science B.V. All rights reserved.
\end{abstract}

Keywords: Bioseparations; Affinity; Chromatography; Glucoamylase

\section{Introduction}

Cyclodextrins (CD) are composed of doughnut-shaped glucose units and are produced through the degradation of starch by the enzyme cyclodextrin transglycosylase. They have no end groups susceptible to be attacked, they are completely resistant towards degradation by $\beta$-amylases, and are only slowly degraded by the $\alpha$-amylases [1].

Selective binding nature of CDs to various substrates can be used for chromatography. For example, a Sepharose column incubated with $\alpha$-cyclodextrin can separate $\beta$-amylase from albumin, though the same column incubated in the absence of $\alpha$-cyclodextrin, cannot [2].

It was reported that amyloglucosidases (AMG) are specifically adsorbed onto Cyclodextrin-Sepharose-6B affinity support [3]. Most of the studies performed for AMG using raw starch and CDs are for characterization, investigation of binding domain, and hydrolysis of starch. Thus, it had been thought that there would be a need to investigate the binding of enzyme on insoluble substrate and its subsequent desorption.

\footnotetext{
* Corresponding author. Fax: +90-232-4453788.

E-mail addresses: sharsa@likya.iyte.edu.tr (S. Harsa), furusaki@life.sojo-u.ac.jp (S. Furusaki).

${ }^{1}$ Fax: +81-96-326-3000.
}

With this frame in mind, we have previously studied the adsorption and desorption behaviour of a single AMG enzyme on $\beta$-CD-chitosan matrix in batch mode in well-stirred vessels. The results have been published elsewhere and included the effect of environmental conditions (i.e. $\mathrm{pH}$, ionic strength and temperature) on the partitioning behaviour of $\mathrm{AMG} / \beta-\mathrm{CD}$-chitosan system at equilibrium [4]. We have also investigated the binding mechanism of $\alpha$-amylase, lactase and AMG enzymes onto $\beta$-CD-chitosan, separately. AMG was bio-specifically adsorbed onto the $\mathrm{CD}$ whereas $\alpha$-amylase and lactase did not show any biospecific adsorption. Chitosan-only and chitosan-spacer gels showed some degree of adsorption, but the adsorbed enzymes were easily eluted from these gels [5].

In this study, our work focuses on the process for biospecific chromatographic separation of AMG from the mixtures of enzymes (lactase and $\alpha$-amylase) using $\beta$-CD-chitosan affinity matrix. This would provide a valuable procedure for the purification of AMG of fungal origin since $\alpha$-amylase and lactase enzymes are the main contaminants in the fermentation broths of AMG. The optimum process conditions for binding, which were obtained from our previous batch studies, are applied to the column experiments. The purity of the enzyme collected from the column is checked by electrophoresis and the separation performance of the chromatography column is discussed in this paper. 


\section{Materials and methods}

\subsection{Materials}

$\alpha$-Amylase, lactase and AMG were purchased from Novo Nordisk, Japan. They were used without further purification.

Chromatography gel was $\beta$-CD-chitosan (particle size $600 \mu \mathrm{m}$ ) supplied from Japan Organo Co. Ltd. $\beta-C D$ was immobilized onto the chitosan matrix introducing a spacer ethylene glycol-di-glycidyl ether (EGDGE). Pore size of chitosan was $0.1-0.2 \mu \mathrm{m}$ (dry state).

\subsection{Column chromatography}

$20 \mathrm{ml}$ hydrated $\beta$-CD-chitosan gels were equilibrated in $0.1 \mathrm{M}$ acetate buffer, $\mathrm{pH} 4.0$ at room temperature for $48 \mathrm{~h}$ and packed into a column $15 \mathrm{~cm}$ high and $2 \mathrm{~cm}$ in diameter. $1.0 \mathrm{ml}$ lactase $(19.8 \mathrm{mg}), 1.0 \mathrm{ml} \alpha$-amylase $(189.3 \mathrm{mg})$ and $2.0 \mathrm{ml} \mathrm{AMG} \mathrm{(488} \mathrm{mg)} \mathrm{enzymes} \mathrm{were} \mathrm{mixed} \mathrm{in} 30 \mathrm{ml}$ acetate buffer, $\mathrm{pH} 4.0$, and pumped onto the column using a peristaltic pump at a flow rate of $0.5 \mathrm{ml} / \mathrm{min}$ to avoid compacting the resin. Sample and column were equilibrated with the same buffer reflecting the optimal conditions for binding. The column was then washed with the equilibration buffer $(30 \mathrm{ml})$ to remove unbound proteins. The second elution of the column was done by applying the $180 \mathrm{ml}$ acetate buffer, $\mathrm{pH} 4.0$ containing $2.0 \mathrm{M} \mathrm{NaCl}$ to remove the non-specifically bound proteins. Finally, the column was washed with $250 \mathrm{ml}$ of borate buffer, $\mathrm{pH} 8.0$ to recover the tightly bound (bio-specifically bound AMG) proteins. Approximately $5.0 \mathrm{ml}$ fractions were collected using a fraction collector. Fractions were analyzed for protein and enzyme activity. Column chromatography experiments were repeated three times and the average values are reported in this paper.

\subsection{Electrophoretic experiments}

Electrophoretic experiments were conducted using a Biorad Mini-Protean II dual slab cell. Sodiumdodecyl sulphate-polyacrylamide gels $(8 \mathrm{~cm} \times 12 \mathrm{~cm})$ were prepared according to the method of Laemmli [6]. 10-25 $\mu$ l of diluted standard proteins and samples were applied into the wells. Molecular weight (MW) standards 30,000-200,000 Da range (Sigma MW-SDS-200 kit) was used for measuring the MW of protein samples (standards: carbonic anhydrase, 29,000; egg albumin, 45,000; BSA, 66,000; Phosphorylase B 97,400; $\beta$-galactosidase, 116,000; and myosin, 205,000).

Gel composition of $7.5 \%$ was used to prepare the gels. Proteins and samples were diluted in a sample buffer in a volume ratio of 2:3 sample to buffer. Samples were diluted to $1 \mathrm{mg} / \mathrm{ml}$; BSA, $0.71 \mathrm{mg} / \mathrm{ml}$; egg albumin, $1 \mathrm{mg} / \mathrm{ml}$, and carbonic anhydrase, $0.5 \mathrm{mg} / \mathrm{ml}$. The samples were heated with sample buffer at $100^{\circ} \mathrm{C}$ for $2 \mathrm{~min}$. The voltage was set to $200 \mathrm{mV}$ and the gel was run at a constant current setting of $25 \mathrm{~mA}$ until the tracking dye arrived at the bottom of the gel (about $50 \mathrm{~min}$ ).
Each protein (lactase, $\alpha$-amylase, AMG) was applied to the SDS-PAGE gel for the measurement of their molecular weights, separately. Also mixed enzyme solution was checked for purity.

\subsection{Analytical methods}

\subsubsection{Protein assays}

The protein concentration of fractions collected from the chromatography column was determined by measurement of absorbance at $280 \mathrm{~nm}$. In addition, the Lowry protein method [7] was used to determine the specific activities of the enzyme solutions.

\subsubsection{Assay of AMG activity}

AMG activities were measured using the method of Novo Nordisk [8]. $1 \mathrm{ml}$ of enzyme solutions were incubated with $1.0 \mathrm{ml}$ preheated substrate solution $(2 \%$ maltose substrate in $0.1 \mathrm{M}$ acetate buffer, $\mathrm{pH} 4.3$ ) at $25^{\circ} \mathrm{C}$ for $30 \mathrm{~min}$. After stopping the reaction with $3.0 \mathrm{ml}$ of $1.66 \mathrm{M}$ tris buffer, $\mathrm{pH}$ 7.6, the reducing sugar formed was assayed using the glucose kit purchased from Boehringer Mannheim and the degree of hydrolysis was determined according to Novo's analytical method.

\subsubsection{Assay of $\alpha$-amylase activity}

$\alpha$-Amylase activities were measured using Wako amylase iodo-starch method. $20 \mu \mathrm{l}$ of enzyme solutions were incubated with $1.0 \mathrm{ml}$ of the preheated substrate buffer solution $(0.25 \mathrm{~mol} / \mathrm{l}$ phosphate buffer, $\mathrm{pH} 7.0$, containing $40 \mathrm{mg} / \mathrm{dl}$ soluble starch) at $37^{\circ} \mathrm{C}$ for $7.5 \mathrm{~min}$. The incubation was terminated with the addition of color reagent which reacted with remaining starch that was not hydrolyzed by amylase in the specimen. The amount of starch hydrolyzed is calculated by substracting the residual amount and is directly proportional to the activity of amylase in the specimen. The amount of hydrolysis was calculated according to the Wako manual. One unit is the amount of amylase activity in $100 \mathrm{ml}$ of solution that catalyzes the hydrolysis of $10 \mathrm{mg}$ of starch in $30 \mathrm{~min}$ at $37^{\circ} \mathrm{C}$.

\section{Results and discussion}

\subsection{Column chromatography}

Results on the chromatographic separation of AMG enzyme from the mixture of the contaminating proteins are given in Table 1 and Fig. 1.

Chromatographic experiments were conducted at $\mathrm{pH} 4.0$ since this is the optimum $\mathrm{pH}$ for the AMG adsorption and since the enzyme is very stable at this $\mathrm{pH}$ value. Besides $\alpha$-amylase and lactase lose their activity at this $\mathrm{pH}$ value and interactions between $\beta-\mathrm{CD}$-chitosan and contaminating proteins are minimum [4,5]. Therefore, $\mathrm{pH} 4.0$ was selected as optimum for the separation of AMG. 
Table 1

Elution yields of $\beta$-CD-chitosan affinity column

\begin{tabular}{|c|c|c|c|}
\hline & Non-binding fraction ${ }^{\mathrm{a}}$ & $2.0 \mathrm{M} \mathrm{NaCl}^{\mathrm{a}}$ & Borate buffer, $\mathrm{pH} 8.0$ eluate \\
\hline Volume (ml) & 58.0 & 173.6 & 228.0 \\
\hline Total protein (mg) & 341.6 & 80.0 & 263.4 \\
\hline Protein concentration $(\mathrm{mg} / \mathrm{ml})$ & 5.9 & 0.5 & 1.2 \\
\hline Total AMG activity (U) & 147.0 & 90.3 & 293.7 \\
\hline Specific activity (U/mg) & 0.4 & 1.1 & 1.1 \\
\hline Enzyme yield (\%) & 27.7 & 17.0 & 55.3 \\
\hline
\end{tabular}

${ }^{\mathrm{a}}$ In $\mathrm{pH} 4.0$ acetate buffer eluate.

In a mixture of proteins the binding capacity of a chromatography gel for the desired protein may differ greatly from its theoretical capacity for a pure protein. Therefore, to ensure that there would be no sample loading effect, the amount of the affinity gel required should be considerably larger (e.g. about 5-10 times) than is calculated from the binding protein capacity. Approximately $20 \mathrm{ml}$ of hydrated $\beta$-CD-chitosan were packed into the column. The gel:liquid volume ratio used here provides that there are sufficient binding sites available for total AMG adsorption $\left(V_{\mathrm{g}} / V=0.7\right.$ was used to size the affinity gel). The maximum adsorption capacity of the gel was larger than $110 \mathrm{mg} / \mathrm{ml}$ hydrated gel at $\mathrm{pH} 4.0$ [5].

The solution applied to the column contained $531 \mathrm{U}$ of AMG enzyme activity. The specific activity of AMG was around $1.1 \mathrm{U} / \mathrm{mg}$. As is evident from Table 1, $147 \mathrm{U}$ of AMG activity $(27.7 \%)$ did not bind to the column and was collected from the outlet. Unbound proteins were removed by washing with the equilibration buffer solution ( $\mathrm{pH} 4.0$ acetate buffer). Washing removed approximately $50 \%$ of the total protein and $\mathrm{AMG}$ enzyme activity was detected in the non-binding fraction. Totally, 90.3 U (17\%) AMG activity was eluted with $2.0 \mathrm{M} \mathrm{NaCl}$ in $\mathrm{pH} 4.0$ acetate buffer. $\alpha$-Amylase was

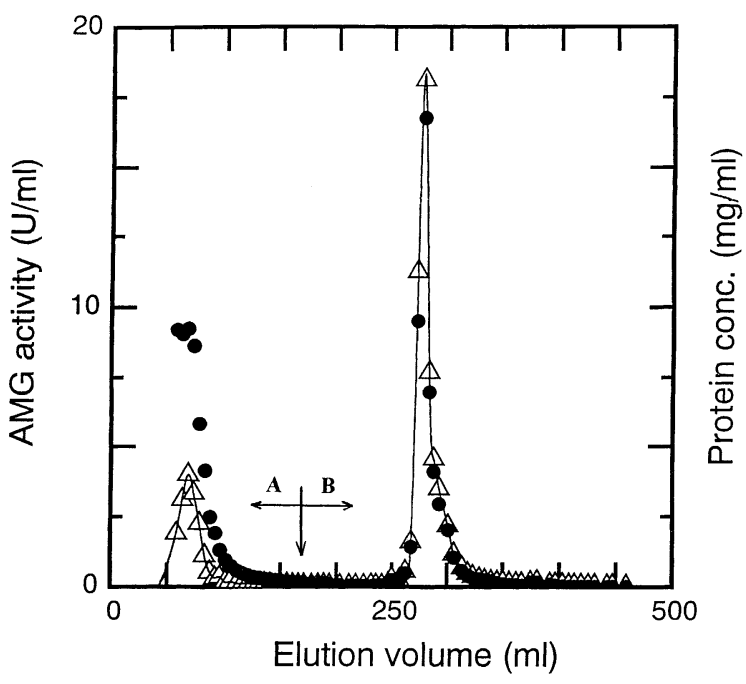

Fig. 1. Elution of AMG and total protein from the affinity column $((\triangle)$ : AMG enzyme activity, ( $)$ : total protein); A: acetate buffer, $2 \mathrm{M} \mathrm{NaCl}$, pH 4.0; B: borate buffer, $\mathrm{pH}$ 8.0. found in the fractions collected from the first and second elutions, and around $48 \% \alpha$-amylase activity was recovered in these eluates. $\alpha$-Amylase activity could not be detected completely in the eluates because its activity was lost very rapidly below pH 5.0 (i.e. approximately $40 \%$ of $\alpha$-amylase activity is remained at $\mathrm{pH} 4.0$ ).

In order to remove the bio-specifically bound AMG, the bound fraction was eluted by increasing the $\mathrm{pH}$ of the buffer solution from 4.0 to 8.0. As can be seen in Fig. 1, an AMG peak was obtained; $293.7 \mathrm{U}$ (55.3\%) AMG activity was eluted with $\mathrm{pH} 8.0$ borate buffer.

The bio-specifically adsorbed and non-adsorbed forms of AMG were identified by some researchers. Dalmia and Nikolov [9] reported that Aspergillus niger amyloglucosidase occurred in two main forms, GA-I (higher molecular weight) bound strongly to the starch surface. GA-II bound to starch weakly and non-specifically and was washed easily from the starch surface with buffer solution. Studies with other amyloglucosidases also have indicated that larger AMG possesses a specific domain, separated from the active site that allows reversible binding of the enzyme to raw starch. Fukuda et al. [10] showed that AMG-I (MW 90,000) was specifically adsorbed onto CD-Sepharose 6B, but AMG-II (MW 73,000) from the same strain was not adsorbed onto that gel. The hydrophobic adsorption of AMG-I onto cyclodextrins and raw starch occurred competitively at the C-terminal side of glycopeptide-I (Gp-I) of CD, and inclusion complexes were formed. Thus, AMG-I was specifically adsorbed onto CD-Sepharose 6B, but AMG-II was not adsorbed. AMG-I was adsorbed onto starch granule at the Gp-I region.

\subsection{Electrophoretic analysis}

SDS-PAGE was conducted in order to check the purity of AMG enzyme recovered from the column and to estimate the molecular weights of the proteins for characterization purposes.

Fig. 2 shows the AMG enzyme with $7.5 \%$ SDS-gel with standard proteins. From a calibration curve derived from the results on standard proteins of known molecular weights, AMG used in this study is found to be having two forms. The upper bands in lanes 5 and 6 in Fig. 2 correspond to the high MW AMG with an estimated MW of 120,000 Da. 


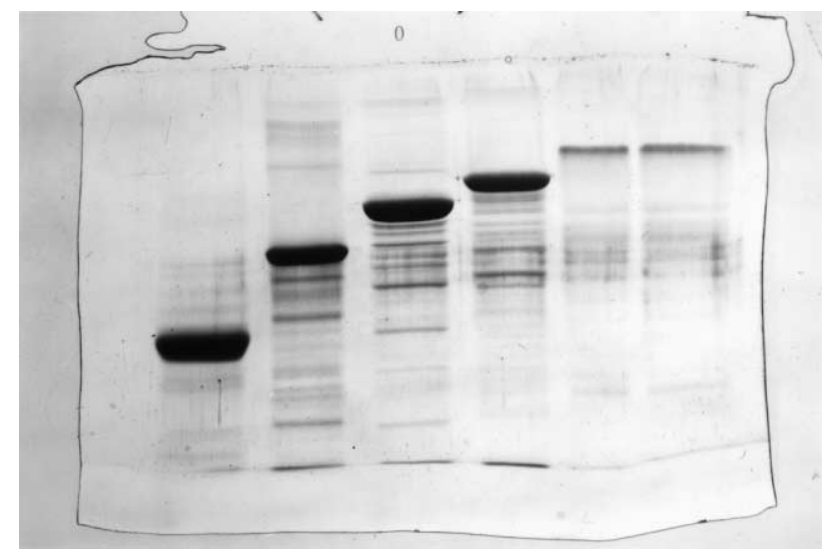

Fig. 2. Molecular weight of AMG (Novo) enzyme (lane 1: egg albumin $(45,000 \mathrm{Da})$; lane 2: BSA $(66,000 \mathrm{Da})$; lane 3: Phosphorylase B $(97,400 \mathrm{Da})$; lane 4: $\beta$-galactosidase $(116,000 \mathrm{Da})$; lane 5: AMG (Novo, $7.5 \mu \mathrm{l})$; lane 6: AMG (Novo, $10 \mu \mathrm{l})) .7 .5 \%$ of SDS-PAGE.

The several faint lower bands correspond to the low MW AMG and the average of these faint bands are calculated as $60,000 \mathrm{Da}$. Our findings on molecular weight are in good agreement with the results of other researchers. A. niger AMG is produced in two main forms having MWs of around 60,000-100,000 Da [11].

Fig. 3 is the 7.5\% SDS-gel, lanes 4 and 5 show $\beta$-galactosidase and $\alpha$-amylases, respectively. While the molecular weight of lactase was $116,000 \mathrm{Da}, \alpha$-amylase was found to be $50,000 \mathrm{Da}$.

Fig. 4 shows the profiles of the mixtures of enzymes (lactase $+\alpha$-amylase + AMG) applied to the column (lane 1), eluted fractions with $\mathrm{NaCl}$ (lane 2) and the purified fractions of AMG after affinity chromatography (lane 3). From lane 2 , it is understood that the low MW AMG which had been adsorbed by $\beta-\mathrm{CD}$ was eluted by $2 \mathrm{M} \mathrm{NaCl}$ buffer since the binding is by electrostatic interactions. From lane 3, it can be easily seen that there is no contaminating proteins (lac-

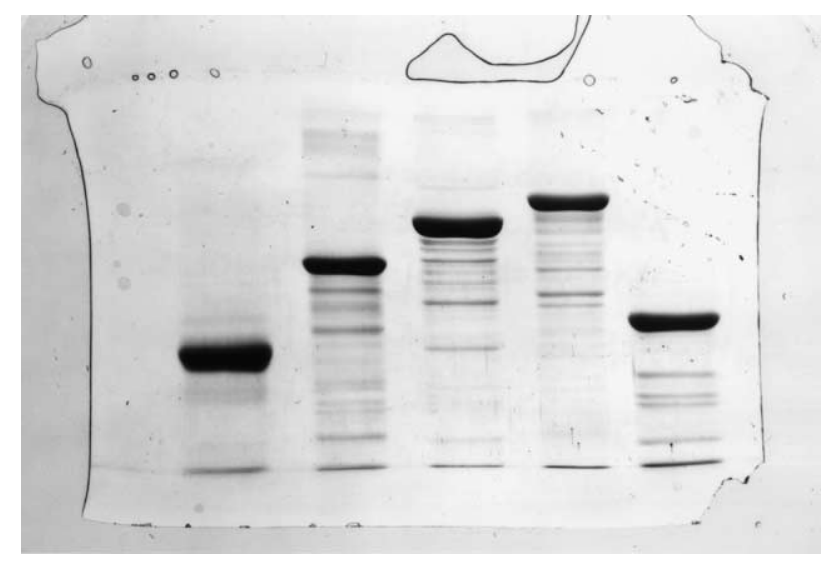

Fig. 3. Molecular weight of lactase and $\alpha$-amylase enzymes (lane 1: egg albumin (45,000 Da); lane 2: BSA (66,000 Da); lane 3: Phosphorylase B $(97,400 \mathrm{Da})$; lane 4: lactase; lane 5: $\alpha$-amylase). $7.5 \%$ of SDS-PAGE.

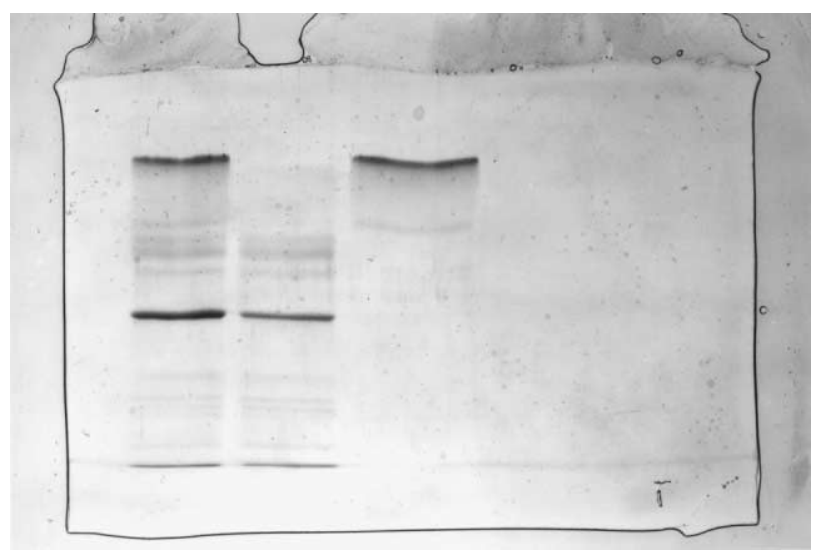

Fig. 4. Photograph of AMG enzyme on 7.5\% of SDS-PAGE gels. (lane 1: mixtures of enzymes applied to the column, lactase $+\alpha$-amylase + AMG; lane 2: eluted fraction of proteins using $\mathrm{NaCl}$; lane 3 : purified fractions of AMG).

tase and $\alpha$-amylase), and that the purified fractions show no other enzyme bands. Therefore, high MW AMG was purified by the $\beta$-CD-chitosan column with $\mathrm{pH} 8.0$ borate buffer.

\section{Conclusions}

AMG used in the study was found to be having two forms, low and high MW AMG, with the corresponding MWs of 60,000 and $120,000 \mathrm{Da}$, respectively. The MW of $\alpha$-amylase was calculated as $50,000 \mathrm{Da}$, while that of lactase as $116,000 \mathrm{Da}$.

At the operating $\mathrm{pH}$ of $4.0, \alpha$-amylase and lactase lost their activities. A fraction of AMG and almost all of the contaminating proteins did not bind on the $\beta$-CD-chitosan column and they were eluted with the equilibration buffer solutions.

The purification of AMG was achieved in two successive elution steps. The first elution was done by acetate buffer with $2 \mathrm{M} \mathrm{NaCl}, \mathrm{pH} 4.0$, and recovered the non-specifically, probably electrostatically bound low MW AMG. This AMG was eluted together with a small amount of $\alpha$-amylase with a recovery yield of $17 \%$. The second elution was done by borate buffer, $\mathrm{pH} 8.0$, and recovered the bio-specifically adsorbed high MW AMG. After this step, there was no contaminating proteins (lactase and $\alpha$-amylase) left in the purified fractions. As a result, high MW AMG was obtained at a very high purity with a recovery yield of $55 \%$. Combining the two eluates containing low and high MW AMGs, the recovery yield was around $72 \%$ (based on the AMG activity) with a specific activity of $1.1 \mathrm{U} / \mathrm{mg}$.

These results indicate that amyloglucosidases can be effectively purified using a simple chromatographic method of $\beta$-CD-chitosan, in which AMG was selectively adsorbed and then desorbed from the cyclodextrin column separating it from the other contaminating enzymes. 
In the light of our study, further research can be carried out using actual fermentation broths. Recovery changes with the number of usage of the column should also be investigated in future studies.

\section{Acknowledgements}

The authors gratefully acknowledge Japan Organo Ltd. for providing the adsorbent throughout this study.

\section{References}

[1] S. Harsa, Y. Goksungur, U. Guvenc, in: U. Guvenc, M. Ucuncu (Eds.), Proceedings of the 6th International Congress on Food Industry, Kusadasi, Izmir, 1997, pp. 68-78.
[2] P. Vretblad, FEBS Lett. 47 (1974) 86-89.

[3] S. Hayashida, K. Nakahara, W. Kanlayakrit, T. Hara, Y. Teramoto, Agric. Biol. Chem. 53 (1989) 143-149.

[4] S. Harsa, S. Furusaki, Sep. Sci. Technol. 29 (5) (1994) 639-650.

[5] S. Harsa, S. Furusaki, Sep. Sci. Technol. 30 (13) (1995) 2695-2706.

[6] U.K. Laemmli, Nature 227 (1970) 680-685.

[7] O.H. Lowry, N.J. Rosebrough, A.L. Farr, R.J. Randall, J. Biol. Chem. 193 (1951) 265-275.

[8] Novo Nordisk, Product Sheet of AMG, Enzyme Process Division, 1992.

[9] B.K. Dalmia, Z.L. Nikolov, Enzyme Microb. Technol. 13 (1991) 982-990.

[10] K. Fukuda, Y. Teramoto, M. Goto, J. Sakamoto, S. Mitsuike, S. Hayashida, Biosci. Biotech. Biochem. 56 (4) (1992) 556-559.

[11] K. Aunstrup, in: B. Wingard, E. Katchalshi-Katzir, L. Goldstein (Eds.), Applied Biochemistry and Bioengineering, Vol. 2, Academic Press, New York, 1979, pp. 28-68. 